\section{References}

1 Vila L, Liu H, Al-Quran SZ, et al. Identification of c-kit gene mutations in primary adenoid cystic carcinoma of the salivary gland. Mod Pathol 2009;22:1296-1302.

2 Holst VA, Marshall CE, Moskaluk CA, et al. KIT protein expression and analysis of c-kit gene mutation in adenoid cystic carcinoma. Mod Pathol 1999;12: 956-960.

3 Jeng YM, Lin CY, Hsu HC. Expression of the c-kit protein is associated with certain subtypes of salivary gland carcinoma. Cancer Lett 2000;154:107-111.

4 Sorensen KB, Godballe C, de Stricker K, et al. Parotid carcinoma: expression of kit protein and epidermal growth factor receptor. J Oral Pathol Med 2006;35: 286-291.

5 Lin $\mathrm{CH}$, Yen RF, Jeng YM, et al. Unexpected rapid progression of metastatic adenoid cystic carcinoma during treatment with imatinib mesylate. Head Neck 2005;27:1022-1027.

6 Aubry MC, Heinrich MC, Molina J, et al. Primary adenoid cystic carcinoma of the lung: absence of KIT mutations. Cancer 2007;110:2507-2510.

7 Marchetti A, Felicioni L, Buttitta F, et al. Assessing EGFR mutations. N Engl J Med 2006;354:526-528.
8 Catalogue of Somatic Mutations in Cancer [database on the Internet] 2009. Wellcome Trust Sanger Institute [cited 2009]. Available from http://www.sanger.ac.uk/ genetics/CGP/cosmic/.

9 Alcedo JC, Fabrega JM, Arosemena JR, et al. Imatinib mesylate as treatment for adenoid cystic carcinoma of the salivary glands: report of two successfully treated cases. Head Neck 2004;26:829-831.

10 Heinrich MC, Joensuu H, Demetri GD, et al. Phase II, open-label study evaluating the activity of imatinib in treating life-threatening malignancies known to be associated with imatinib-sensitive tyrosine kinases. Clin Cancer Res 2008;14:2717-2725.

11 Faivre S, Raymond E, Casiraghi O, et al. Imatinib mesylate can induce objective response in progressing, highly expressing KIT adenoid cystic carcinoma of the salivary glands. J Clin Oncol 2005;23:6271-6273.

12 Hotte SJ, Winquist EW, Lamont E, et al. Imatinib mesylate in patients with adenoid cystic cancers of the salivary glands expressing c-kit: a Princess Margaret Hospital Phase II Consortium Study. J Clin Oncol 2005;23:585-590.

13 Pfeffer MR, Talmi Y, Catane R, et al. A phase II study of imatinib for advanced adenoid cystic carcinoma of head and neck salivary glands. Oral Oncol 2007;43:33-36.

\title{
Response to Moskaluk et al
}

\author{
Modern Pathology (2010) 23, 906-907; doi:10.1038/modpathol.2010.64
}

To the Editor: It is with great interest that we read the comments by Moskaluk et $a l^{1}$ in relation to our paper titled 'Identification of $c$-kit gene mutations in primary adenoid cystic carcinoma of the salivary gland' published in the October 2009 issue of Modern Pathology. We appreciate the comments from the authors, who are wellestablished investigators in the field. We understand the authors' concerns regarding the introduction of artifactual mutations using formalin-fixed paraffinembedded tissue (FFPE); ${ }^{2}$ however, as the study by Marchetti et al illustrates, these artifacts are likely to be observed when very small amounts of starting DNA (5 ng) are isolated and subjected to multiple PCR amplifications. As Marchetti et al point out, 'the occurrence of these artifacts can be prevented with the use of larger amounts of template DNA (at least $1 \mu \mathrm{g}$ of DNA recovered from paraffin).' In our study, we measured the DNA content obtained after extraction to ensure that all tumor samples contained greater than $1.5 \mu \mathrm{g}$ of starting template DNA. Moreover, tissue samples (which were obtained from large surgical resections and not small biopsies) were microdissected to minimize contamination from surrounding normal tissue and were subjected to a single PCR reaction, using a methodology similar to that outlined by Antonescu et al. ${ }^{3}$
Although the finding of more than one exon mutation in the $c$-kit gene is rare as Moskaluk et al note, ours is not the first study to report multiple $c$-kit mutations within the same tumor and loss or addition of mutations in primary versus metastatic tumor. ${ }^{4,5}$ Multiple mutations were quite common in the series of Andersson et al, who utilized subcloning of PCR products for exons 12-15 and direct sequencing of exons 9-11 from fresh-frozen tissue of gastrointestinal stromal tumors (GISTs). ${ }^{4}$ In this study, six of nine tumors with mutations in exons 11 had one or two additional mutations in exons 14 and 15 . In addition, different mutations were found in the primary tumor versus secondary tumor, indicating the complexity between c-kit mutations and clinical behavior. These findings suggest the heterogeneity of tumor cells found within the same population and existence of subpopulations of tumor cells with different mutations. These subpopulations would not be detected by direct sequencing of PCR products, which requires the mutation subpopulation to consist of at least $15-20 \%$ of the total PCR product.

Although we cannot exclude with absolute certainty the introduction of artifactual mutations in this type of analysis, we believe these represent rare events. In fact, in our study, the majority of clones 
sequenced for each tumor represented the wild-type sequence, with only a minority expressing point mutations. The majority of point mutations were found in exon 11, which is the most frequent exon mutated in the $c$-kit gene of GISTs. We expect that, if the mutations detected were due to artifacts caused by DNA damage that occurs during processing of FFPE tissue as Moskaluk et al suggest, we would have seen an equal distribution of mutations across all exons. Instead, we found the majority of point mutations clustering in the $5^{\prime}$ and $3^{\prime}$ regions of exon 11 , with a minority of $c$-kit mutations occurring in exons 9, 13, and 17, as reported in GISTs. The finding of $c$-kit mutations in exact mutational hotspots as described in GISTs (ie, Leu576Phe, Val643Ala, Asn822Ser) ${ }^{6-8}$ further adds to the validity of our results.

We agree with Moskaluk et al that published data from prospective clinical studies examining the role of anti-KIT-directed therapy have shown a very low response rate ${ }^{9-13}$ and that therapeutic decisions should be made with caution. We recognize the limitations of our study, given our small sample size and lack of frozen-matched controls, which were not available for us to analyze at the time of this study. We hope that our paper would encourage further examination of the $c$-kit gene in adenoid cystic carcinomas of the salivary gland (ACCSG) using better sequencing approaches, such as subcloning or 454 sequencing; otherwise, we may miss small subpopulations of $c$-kit mutations in tumor samples.

We have acknowledged in our conclusions in the paper that future studies in a larger series are needed to determine the prognostic and therapeutic implications of $c$-kit mutations in ACCSG. We have begun our efforts to collect frozen tumor and fresh cell lines of ACCSG for further study, and hope that we can collaborate with other centers in these efforts.

Lizette Vila, Hongyan Liu, Samer Z Al-Quran, Dominique P Coco, Hui-Jia Dong and Chen Liu Department of Pathology, Immunology, and Laboratory Medicine, University of Florida, Gainesville, FL, USA E-mail: lvila@pathology.ufl.edu

\section{References}

1 CA Moskaluk, HF Jr Frierson, AK El-Naggar, et al. $c$-kit gene mutations in adenoid cystic carcinoma are rare. Mod Pathol 2010;23:905-906 (this issue).

2 Marchetti A, Felicioni L, Buttitta F, et al. Assessing EGFR mutations. N Engl J Med 2006;354:526-528.

3 Antonescu CR, Sommer G, Sarran L, et al. Association of KIT exon 9 mutations with nongastric primary site and aggressive behavior: KIT mutation analysis and clinical correlates of 120 gastrointestinal stromal tumors. Clin Cancer Res 2003;9:3329-3337.

4 Andersson J, Sjögren H, Meis-Kindblom JM, et al. The complexity of KIT gene mutations and chromosome rearrangements and their clinical correlation in gastrointestinal stromal (pacemaker cell) tumors. Am J Pathol 2002;160:15-22.

5 Sakurai S, Oguni S, Hironaka M, et al. Mutations in $c$-kit gene exons 9 and 13 in gastrointestinal stromal tumors among Japanese. Jpn J Cancer Res 2001;92:494-498.

6 Zamò A, Bertolaso A, Franceschetti I, et al. Microfluidic deletion/insertion analysis for rapid screening of KIT and PDGFRA mutations in CD117-positive gastrointestinal stromal tumors: diagnostic applications and report of a new KIT mutation. J Mol Diagn 2007;9:151-157.

7 Gomes AL, Bardales RH, Milanezi F, et al. Molecular analysis of $C$-Kit and PDGFRA in GISTs diagnosed by EUS. Am J Clin Pathol 2007;127:89-96.

8 Lasota J, Wozniak A, Sarlomo-Rikala M, et al. Mutations in exons 9 and 13 of KIT gene are rare events in gastrointestinal stromal tumors. A study of 200 cases. Am J Pathol 2000;157:1091-1095.

9 Hotte SJ, Winquist EW, Lamont E, et al. Imatinib mesylate in patients with adenoid cystic cancers of the salivary glands expressing c-kit: a Princess Margaret Hospital phase II consortium study. J Clin Oncol 2005;23:585-590.

10 Pfeffer MR, Talmi Y, Catane R, et al. A phase II study of Imatinib for advanced adenoid cystic carcinoma of head and neck salivary glands. Oral Oncol 2007;43:33-36.

11 Ochel HJ, Gademann G, Röcken C, et al. Effects of imatinib mesylate on adenoid cystic carcinomas. Anticancer Res 2005;25:3659-3664.

12 Faivre S, Raymond E, Casiraghi O, et al. Imatinib mesylate can induce objective response in progressing, highly expressing KIT adenoid cystic carcinoma of the salivary glands. J Clin Oncol 2005;23:6271-6273.

13 Alcedo JC, Fábrega JM, Arosemena JR, et al. Imatinib mesylate as treatment for adenoid cystic carcinoma of the salivary glands: report of two successfully treated cases. Head Neck 2004;26:829-831. 